\title{
Örgütsel Sağlığın Lider-Üye Etkileşimi ve Whistleblowing Üzerindeki Etkisi: Otel İşletmelerinde Bir Alan Araştırması
}

\author{
The Effect of Organizational Health on Leader-Member Exchange and \\ Whistleblowing: A Field Research in Hotel Businesses
}

Hüseyin ÇİÇEKLİOĞLU ${ }^{1}$, Anıl KALE ${ }^{2}$

\begin{abstract}
$\ddot{\mathbf{O z}}$
Amaç: $\mathrm{Bu}$ araştırmanın amacı; otel işletmelerinde çalışan bireylerin örgütsel sağlık algılarının whistleblowing ve lider üye etkileşimi düzeyleri üzerindeki etkisini tespit etmektir. Bu amacın yanı sıra; araştırma değişkenleri arasındaki ilişkilerin yönünün ve düzeyinin de belirlenmesi amaçlanmıştır.

Tasarım/Yöntem: Bu araştırmada Doğu Akdeniz bölgesinde yer alan bir ildeki beş yıldızlı iki otelde görev yapan çalışanlar üzerinde kolayda örnekleme yöntemiyle belirlenen 128 çalıșana anket uygulanmıştır. Elde edilen veriler SPSS aracılığıyla analize tabi tutulmuştur.

Bulgular: Araştırma sonuçlarına göre; örgütsel sağlığın whistleblowing ve lider üye etkileşimini pozitif yönde etkilediği tespit edilmiștir. Örgütsel sağlık düzeyi arttıkça whistleblowing ve lider üye etkileşim düzeyleri artmaktadır. Bununla birlikte lider üye etkileşim düzeyi arttıkça whistleblowing davranışlarının arttı̆̆ı tespit edilmiştir.
\end{abstract}

Sinırlılıklar: $\mathrm{Bu}$ araștırma sonucunda ortaya konulan sonuçlar; çözülmesi amaçlanan problem, ele alınan değiş̧enler, kullanılan yöntem, belirlenen örneklem ve başvurulan istatistiksel analiz teknikleri kapsamında üretilmiștir. Dolayısıyla bir dizi sınırlılık mevcuttur. Alan araştırması kapsamında toplanan veriler kesitsel bir özellik göstermekte ve Doğu Akdeniz bölgesinde yer alan bir ildeki beş yıldızlı iki otelde görev yapan çalışanlardan oluşmaktadır. Özgünlüik/Değer: Araştırma kapsamında ele alınan değişkenlerin ilgili alan yazında gri bir alan bırakması, üç değişkenin bir arada ele alınmamış olması, alan yazındaki boşluğu doldurmaya katkı sağlaması adına önem ve özgünlük arz etmektedir.

Anahtar Kelimeler: Örgütsel Sağlı, Lider Üye Etkileşimi, Whistleblowing

\begin{abstract}
Purpose: This research aims to determine the effect of organizational health perceptions of individuals working in hotel businesses on whistleblowing and leader-member exchange levels. Besides this purpose; it was also aimed to determine the direction and level of the relations among the research variables

Design/Methodology: In this research, a questionnaire was applied to 128 employees who were determined by convenience sampling method on employees working in two five-star hotels in a province in the Eastern Mediterranean region. The obtained data were analyzed by SPSS

Findings: According to the research results; It has been determined that organizational health has a positive effect on whistleblowing and leader-member exchange. As the level of organizational health increases, whistleblowing and leader-member exchange levels increase. However, it was determined that whistleblowing behaviours increased as the leader-member interaction level increased.

Limitations: The results of this research were produced within the scope of the problem aimed to be solved, the variables considered, the method used, the sample determined and the statistical analysis techniques applied. Therefore, there are several limitations. The data collected within the scope of the field study show a cross-sectional feature and consist of employees working in two five-star hotels in a province in the Eastern Mediterranean region.

Originality/Value: The fact that the relationship between brand satisfaction, trust and loyalty is examined in a limited number within the scope of social media communication despite intensive work in other fields, and reaching results that can contribute to the social media communication strategies of brands constitutes the original value of the research.

Keywords: Organizational Health, Leader-Member Exchange, Whistleblowing
\end{abstract}

\footnotetext{
${ }^{1}$ Öğr. Gör. Dr., Mersin Üniversitesi, Turizm Fakültesi, Turizm Rehberliği Bölümü, huseyinciceklioglu@ gmail.com, ORCID: 0000-0003-3922-6755

${ }^{2}$ Dr. Öğr. Üyesi, Mersin Üniversitesi, Turizm Fakültesi, Rekreasyon Yönetimi Bölümü, anilkale@mersin.edu.tr, ORCID: 0000-0002-6530-2910
} 


\section{GİRIŞ}

Sürdürülebilir rekabetçi avantajin sağlanabilmesi, örgütsel amaç ve hedeflere ulaş1labilmesi, çalışan verimliliğinin, performansının ve etkililiğinin artırılmasındaki en önemli unsurların başında sağlıklı bir örgüt yapısının kurulması ve lider üye arasındaki etkileşimin sağlanması gelmektedir. Sağlıklı örgütlerde çalışan, lider ve yöneticileriyle doğru iletişimi kurabilen bireylerin motivasyon ve örgütsel aidiyet düzeyleri güçlü olmaktadır.

Sağlıklı bir örgüt; çalışanların biçimsel olmayan rol davranışları sergilemeye mecbur bırakılmadan örgüte uyum sağladığı, çalışanlar arasında meydana gelen çatışmaların örgütsel amaçlar doğrultusunda yönetildiği, uzun vadeli yaşamını sürdürebilmek adına gereksinimlerini karşılayabilen, büyüme ve gelişme faaliyetlerini yerine getiren örgütlerdir (Kurum, 2013: 12). Hem örgüt hem de çalışan sağlığını kapsayan bir çatı görevi gören bu tarz örgütlerde çalışan bireylerin çevreye uyum sağlama, amaç ve hedefleri gerçekleştirebilme yetenekleri ile etkinlik, verimlilik ve performans düzeyleri üst düzeyde olmaktadır. Sağlıklı örgütlerde lider ve üye arasındaki etkileşim yüksek seviyelerde gerçekleşmekte, örgütsel bağl1lık ve vatandaşlık davranışları artış göstermekte ve işten ayrılma niyetleri ise azalmaktadır.

Canlı bir organizma özelliği gösteren örgütler, tıpkı insanlar gibi belirli bir toplum içerisinde faaliyet göstermektedirler. Söz konusu bu örgütler, toplumların refah düzeylerini artıran faaliyetleri gerçekleştiren, yeni teknoloji, bilgi, ürün ve hizmetleri insanlığın kullanımına sunan, toplumların sosyal ve ekonomik açıdan gelişimini destekleyen unsurlar olarak ele alınabileceği gibi faaliyetleri ile toplum nezdinde etik değerlerin ortadan kalkmasına neden olan yozlaşma, ahlak dışı davranışlar ve yolsuzlukların ortaya çıkartılmasını kolaylaştıran unsurlar olarak da değerlendirilebilmektedir (Koçel, 2013: 72). İşte bu olguların açığa çıkartılmasında whistleblowing olarak tanımlanan davranış kalıbı kullanılmaktadır. Whistleblowing, bir örgüt içerisinde etik değerlere uygun olmayan ve yasadışı eylem ve davranışların örgüt içi ya da örgüt dışı diğer kişi ve kurumlara zarar vermemesi adına bilgi sahibi kişiler tarafindan sorunları çözme yetki ve gücüne sahip otoritelere aktarılması şeklinde ifade edilmekte olup (Aktan, 2015: 19), alan yazında erdemli raporlama, bilgi ifşası ya da ihbar etme şeklinde de adlandırılmaktadır. Yapılan araştırmalarda (Taylor \& Curtis, 2010; Hoffman vd., 2007; LePine vd., 2002) sağliklı bir örgütte çalışan, örgütsel vatandaşlık, yönetime güven ve iş tatmin düzeyi yüksek olan ve liderleri ile etkileşim kurabilen çalışanların whistleblowing davranışlarına yönelik eğilimlerinin daha yüksek olduğu gözlemlenmektedir.

Geleneksel liderlik yaklaşımları, liderlerin bütün çalışanlarıyla aynı şekilde ilişki kurduğunu düşüncesini savunmaktadır. Fakat lider üye etkileşimi kuramı, liderlerin örgüt çalışanlarının hepsine yönelik standart bir davranış sergileyeceği düşüncesine karşı çıkmakta ve liderin her bir astı ile kurduğu ayrı ayrı ilişkiler üzerine yoğunlaşmaktadır. Liderler, ast konumunda bulunan bazı çalışanları ile karşı1lıklı güven, saygı, beğeni ve etkileşim temelli ilişkiler oluşturmaktadır. Bu ilişki temeli içerisinde yer alan astlar grup içi üyeler olarak tanımlanmaktadır. Bununla birlikte bazı çalışanlarla da geleneksel yönetim yaklaşımları yoluyla ilişkiler kurulmakta ve bu çalışanlar da grup dışı üyeler olarak tanımlanmaktadır. Grup içerisindeki üyeler, grup dışındaki üyelere nazaran liderlerle daha fazla iletişim kurmakta ve liderlerden çok daha fazla ilgi, bilgi, etki ve güven görmektedirler (Zel, 2006: 167). Bu durum ise bireylerin whistleblowinge yönelik eğilimleri üzerinde etkin rol oynamaktadır. Örgüt içerisinde biçimsel rol davranışları sonucu kurulan ilişkiler, iş tatmininin, performansın, etkililiğin ve verimliliğin arttırılması için bir noktaya kadar yeterli olmaktadır. Sürekli ve yoğun değişimlerin yaşandığ1 günümüz iş yaşamında örgütleri başarıya götürecek olan sağliklı örgüt yapısının kurulmasında, lider üye etkileşiminin oldukça büyük önemi vardır. Çünkü lider ve üye arasındaki ilişkinin kalite seviyesi hem çalışan hem de örgüt performansı üzerinde etkilidir. Örgütsel davranış alan yazın incelendiğinde, lider ve astı arasındaki davranış kalıplarının, uyumun ve işbirliğinin örgüt sağlığı adına önemi sıklıkla vurgulanmaktadır (Ünlü, 2011: 3).

Örgütlerin eskisinden daha etkin ve başarılı bir konuma gelebilmesi ve örgütsel amaçlara ulaşılabilmesi için insanlar arasında işbirliklerinin gerçekleştirilmesi son derece önemlidir. Geçmişten günümüze belirlenen amaçların ve söz konusu işbirliklerinin gerçekleştirilmesini sağlamak adına bireyleri çalıştırabilme yeteneklerine haiz lider ve yöneticilere ihtiyaç duyulmaktadır (Cevrioğlu, 2007: 1). Bununla birlikte bu lider ve üye etkileşimi olgusunun örgütlere yönelik faaliyetlerinde 
merkeze bireyi koyması, bireyin varlığının söz konusu olduğu her yerde etkileşim ve iletişimin yadsınamaz olması ve hem iş hem de normal hayatta bireyler arasında iletişimin nasıl başlayıp sürdürüldüğünün tespit edilmesi adına oldukça önemlidir. Çünkü bu etkileşim ve iletişim süreci, çalışanların örgütsel verimliliği ve performansı doğrudan etkileyebilecek algılarına, eylemlerine ve tutumlarına etki etmektedir (Erdem, 2008: 1).

Cemaloğlu'na (2011) göre eğer bir örgütün bütün alt sistemleri etkin ve verimliyse, örgütün iyi bir örgütsel sağlığa sahip olduğu ve hedeflerine ulaşacağı düşünülmektedir. Bu noktada örgütsel sağlık, bir örgütün değişim ve gelişmelerle başa çıkabilecek düzeyde etkin işlev gösterebilme kapasitesini ifade etmektedir. Örgütsel verimlilik, uyum becerisi olarak da ele alınabileceği için sağlıklı bir örgüt yapısında doğru örgütsel gelişmeler ortaya çıkacaktır. Optimum düzeyde kurulan örgütsel sağlık yapıları, örgütlerin etkin ve verimli bir yönetime ve iyi bir lider-üye etkileşimine sahip olduklarını gösterir (Usenyag vd., 2017).

Araştırma kapsamında ele alınan değişkenlerin ilgili alan yazında gri bir alan bırakması, üç değişkenin bir arada ele alınmamış olması, alan yazındaki boşluğu doldurmaya katkı sağlaması adına önem ve özgünlük arz etmektedir. Bununla birlikte bu araştırma sonucunda ortaya konulan sonuçlar; çözülmesi amaçlanan problem, ele alınan değişkenler, kullanılan yöntem, belirlenen örneklem ve başvurulan istatistiksel analiz teknikleri kapsamında üretilmiştir. Dolayısıyla bir dizi sınırlılık mevcuttur. Araştırmanın değişkenler anlamında kapsamını örgütsel sağlık, lider-üye etkileşimi ve whistleblowing oluşturmaktadır. Gerçekleştirilen bu araştırma kesitsel (cross-sectional) bir araştırma olup, Doğu Akdeniz bölgesinde faaliyet gösteren iki adet beş yıldızlı otel işletmelerinde çalışanlar 128 birey ile gerçekleştirilmiştir. Elde edilen veriler SPSS aracılığıyla çeşitli analizlere tabi tutulmuştur.

Araştırma kapsamında, ilk olarak örgütsel sağlık, lider üye etkileşimi ve whistleblowing kavramlarına açıklık getirilecek, sonrasında ise araştırma metodolojisi ve bulgular ortaya koyulacak ve elde edilen araştırma sonuçları yorumlanarak, önerilerde bulunulacaktır.

\section{KAVRAMSAL ÇERÇEVE}

\section{1. Örgütsel Sağlık}

Son dönemlerin hem teorisyenler hem de uygulayıcılar tarafindan ele alınan konularından birisi örgütsel sağlık kavramıdır. Kavramın kökleri 1960'lı yıllardaki çalışmalara dayanmaktadır (Shoaf vd., 2004: 83). Herzberg ve diğerleri (1959), Maslow (1965), Porter ve Lawler (1968) ve Vroom (1964), bireysel motivasyon ile performans arasındaki etkileşimleri araştırmıştır. Argyris (1958; 1964), bir organizasyonun rekabetçi kalırken çalışanlarının ihtiyaçlarını karşılama yeteneğini sorgulamıştır. McGregor'un (1960) Teori X (otoriter yönetim) ve Teori Y (demokratik yönetim) tanımları, örgütsel çevrenin rolünün, çalışan potansiyelini kullanmanın yanı sıra etkinliği belirlemede kritik olduğunu iddia etmiştir. Bu teoriler, örgütsel sağlığın çeşitli yönlerini iyileştirmeyi amaçlayan çok sayıda müdahale çabasının temelini oluşturmuştur.

Okulların iklimini ifade etmek için sağlık metaforu, ilk olarak Mathew Miles tarafindan kullanılmıştır (Tsui \& Cheng, 1999; Gül, 2007; Korkmaz, 2007; Doğan \& Bozkurt, 2008; Sandıkçı vd., 2015). Sağlık metaforu her ne kadar ilk olarak okullardaki iklimi ifade etmek için kullanılsa da her araştırmacı konuyu kendi disiplinine göre değerlendirmektedir (Gül, 2007: 321). Örneğin bir örgütün finansal anlamda incelenmesinde "finansal sağlık" kavramı kullanılabilirken (Chen \& Wong, 2004); örgütlerdeki taraflar arasındaki ilişkilerin iklimini niteleme konusunda "örgütsel sağl1k" kavramı kullanılabilmektedir (Altıntaş, 2019). Miles (1969: 378), sağlıklı bir örgütü; "sadece kendi çevresinde hayatta kalmakla kalmayıp, uzun vadede yeterli bir şekilde başa çıkmaya devam eden ve hayatta kalma ve başa çıkma yeteneklerini sürekli geliştiren ve genişleten” bir organizasyon olarak tanımlamıştır. Akbaba (2001: 11) ise, sağlıklı örgütleri ortaya çıkan sorunları çözebilme yeteneğine sahip olarak değerlendirmiştir.

Örgütsel sağlık kavramı, örgütsel aidiyet, stres, iklim, güven, etkililik ve kültür gibi olguları içeren çok kapsamlı bir bakış açısı sağlamaktadır bir bakış açısını sağlamaktadır (Lyden \& Klingele, 2000: 3). Dolayısıyla sağlıklı örgütler, bir örgütün yoğun rekabet koşullarında uzun vadede ayakta kalabilmesi için önem arz eden gelişme ve büyüme işlevlerini etkin bir şekilde yerine getirebilme 
yeteneğine sahip olan örgütler olarak nitelendirilebilirler. Genel anlamıyla örgütsel sağlık, çalışanların kendilerini huzur içinde hissettiği, olumsuz algılardan uzak olduğu bir iş ortamıdır (Tutar, 2016: 274).

\subsection{Lider-Üye Etkileşimi}

Günümüzde bütün örgütlerde mutlaka bir tür liderlik bulunmaktadır (Andersen, 2006: 1079). Ortak hedeflere ulaşmak, istenilen başarıları elde etmek, ancak ve ancak örgütün içindeki ve dışındaki diğer insanlarla veya onlar aracılığıyla mümkün olabilecektir (Blake \& Mouton, 1985: 198). Bu noktada lider ve takipçileri arasında bir takım etkileşimler meydana gelebilmektedir. Lider-üye etkileşimi, bir lider ile astı arasındaki ilişkinin kalitesi olarak tanımlanmaktadır (Graen \& Uhl-Bien, 1995). Gerçek anlamda kaliteli lider-üye etkileşimi, liderler ve astları arasında yoğun etkileşim neticesinde yüksek düzeyde güven ve saygı ile karakterize edilmektedir (Dienesch \& Liden, 1986). Dolayısıyla etkili liderlik bir anlamda lider ile astları arasında kurulacak iyi ilişkilere bağlı olduğu söylenebilecektir.

Lider-Üye Etkileşimi Teorisi, liderlerin ve astların çeşitli sosyal değişim ilişkileri oluş̧urduğu liderliğe, etkileşimci bir yaklaşım önermektedir (Deluga \& Perry, 1994: 67). Teori temel olarak lider ile astı arasındaki etkileşimin kalitesini açıklamaya çalışmaktadır (Dienesch \& Liden, 1986: 621; Settoon vd., 1996: 225). Teorinin en kritik unsuru ise, rol yapma sürecinden ortaya çıkan bir lider ve ast arasındaki ilişkinin doğasıdır (Dienesch \& Liden, 1986: 624). Teorinin temelini Dansereau ve diğerleri (1975) tarafından geliştirilen "Dikey İkili Bağlantı Modeli" oluşturmaktadır. Bu noktada dikey sözcüğü, lider ve astı arasındaki hiyerarşiyi tanımlarken; ikili sözcüğü ise lider ile astını ifade etmektedir (Liden \& Maslyn, 1998: 45). Model daha sonra Graen (1987) tarafindan Lider-Üye Etkileşimi olarak anılmıştır.

Lider-Üye Etkileşimi Teorisi'ne göre liderin gücü, zamanı ve kaynakları sınırlıdır ve bu nedenle sahip olduğu sınırlı gücü, zamanı ve kaynakları astlarına eşit şekilde ayıramayacaktır (Cashman vd., 1976; Dienesch \& Liden, 1986; Graen, 1976; Graen \& Cashman, 1975; Graen \& Scandura, 1987; Zalesny \& Graen, 1987). Bu yüzden astlarına birbirinden farklı yaklaşımlar sergileyeceklerdir (Wayne vd., 1994: 708). Liderin sahip olduğu sinırlı kaynakları ayırabildiği, diğerlerine göre nispeten daha yakın etkileşimde bulunduğu astlar "grup içi"; diğgerleri ise "grup dışı" olarak anılmaktadır (Dansereau vd., 1975: 56). Grup içi olarak anılan yükssek kaliteli etkileşime erişen astlar, olumlu performans değerlendirmeleri, terfiler, kariyer gelişiminde destek ve özel pozisyonlar dahil olmak üzere özel avantajlar ve firsatlar elde edebilirken; grup dışı olarak anılan ve düşük kaliteli etkileşime erişebilen astlar ise bu özel durumlardan çoğunlukla mahrum kalmakta ve standart örgütsel faydalar elde edebilmektedir (Graen vd., 1990: 5; Yukl, 1989: 267).

\subsection{Whistleblowing (Açık Etme)}

Günümüzde rekabet ortamı teknolojinin de gelişmesiyle örgütleri her anlamda zorlamaktadır. $\mathrm{Bu}$ rekabet koşullarında örgütler ayakta kalabilmek, büyümek, gelişmek ve sürekli olabilmek için, sahip oldukları üretim faktörlerini en iyi şekilde kullanarak çeşitli faaliyetler gerçekleştirmektedirler. Örgütler kimi zaman kasıtlı olarak kimi zaman da istemeyerek örgütler faaliyetlerinde yasaların dışına çıkabilmekte ya da etik kuralları çiğneyebilmektedir. Bunun yanı sıra çalışanlar arasındaki yarış, başarı hırsı da tıpkı örgütler gibi bireyleri de etik ya da yasal sınırların dışına itebilmektedir. Bu olumsuz durumların daha da büyüyüp işletmeye, çevreye ve paydaşlara zarar vermemesi için örgüt içinde hızlı bir şekilde çözülmesi gerekmektedir. Bu noktada whistleblowing kavramı ortaya çıkmaktadır. Whistleblowing, örgüt üyelerinin (eski ya da mevcut) işverenlerinin kontrolü altındaki yasa dışı, ahlaka aykırı ya da gayrimeşru uygulamaların eyleme geçebilecek kişi ya da kuruluşlara bildirilmesi olarak tanımlanmaktadır (Near \& Miceli, 1985: 4).

Whistleblowing kavramı kelime olarak ıslık veya düdük çalma anlamına gelmekle birlikte, Türkçe alanyazında açık etme, olumsuz durumları bildirme, bilgi uçurma, ispiyonculuk, ihbarcılık, bilgi ifşası vb. gibi çok sayıda isimle anılmaktadır. Kavram ilk olarak 1963 yılında ABD'de devlet güvenliği ile ilgili gizli belgeleri Senato İç Güvenlik Alt Komitesi baş danışmanına veren Otto Otopeka hakkında yapılan tanıtımda kullanılmıştır. Whistleblowing kavramının kökeninde İngiliz polislerin, halkı ve diğer polisleri suç eylemlerine karşı uyarmak için düdüklerini çalması yatmaktadır (Hersh, 2002: 243). Kavramın ortaya çıkmasında Enron isimli şirketteki çalışanların, yapılan hileleri ortaya çıkarmalarının da etkili olduğu düşünülmektedir (Kozak \& Şahin, 2018: 2). Whistleblowing 
zamanla bazı ülkeler tarafından resmi raporlarda tartışılmış ve akademik alanyazında yoğun olarak araştırılmaya ve çalışılmaya başlanmıştır.

Whistblowing kavramının içsel, dışsal, gizli ve destekçi olmak üzere dört türü bulunmaktadır (Celep \& Konakl1, 2012: 24-25). Buna göre, eğer bir çalışan örgüt içinde şahit olduğu veya öğrendiği etik veya yasal açıdan yanlış faaliyetler ile ilgili sorunun çözümünü yine örgüt içinde arıyorsa "içsel whistleblowing" olarak adlandırılırken; çalışan olumsuz durumu veya durumları örgüt dişındaki devlete, polise, sivil toplum kuruluşlarına ya da basına aktarıyorsa "dışsal whistleblowing" olarak adlandırılmaktadır. Öte yandan whistblowing yapacak olan çalışan kimliğinin gizli kalmasını, adının diğerleri ile paylaşılmamasını istiyorsa bu durum "gizli whistleblowing" olarak tanımlanmaktadır. Son olarak çalışanların olumsuz durumları birbirleri ile paylaşıp birbirlerini destekleyerek durumu açığa çıkarmaları ise "destekçi whistleblowing" olarak adlandırılmaktadır.

\section{YÖNTEM}

\subsection{Araştırma Amaç ve Kısıtları}

$\mathrm{Bu}$ araştırmanın amacı, otel işletmelerinde görev yapan bireylerin örgütsel sağlık algılarının whistleblowing ve lider üye etkileşimi düzeyleri üzerindeki etkisini belirlemektir. Bununla birlikte; söz konusu üç araştırma değişkeni arasındaki ilişkilerin düzeyinin ve yönünün de tespit edilmesi hedeflenmektedir.

Söz konusu araştırmanın evrenini, Doğu Akdeniz bölgesindeki bir ilde faaliyet gösteren beş yıldızlı iki otel işletmesinde görev yapan çalışanlar oluşturmaktadır. Araştırma evreni büyüdükçe ulaşılması zor hale gelmekte ve git gide soyut bir hal almaktadır. Evreni oluşturan çalışanların sayısının fazla olması nedeniyle deney, mülakat, gözlem ve anket gibi veri toplama yöntemlerinden sadece anket tekniği kullanılmıştır (Karasar, 2005: 110). Evren içerisinden araştırmaya yönelik örneklem tespiti için aşağıdaki formülden yararlanılmıştır (Ural \& Kılıç, 2013: 38).

$$
n=\frac{\mathrm{N} \cdot z^{2} \cdot \sigma^{2}}{(\mathrm{~N}-1) \cdot H^{2}+z^{2} \cdot \sigma^{2}}
$$

Yukarıdaki formülde 0,5 standart sapma, 1,96 anlamlılık düzeyi ve 0,10 örneklem hatas1 değerleri kullanıldığında minimum örneklem sayısının 104 olması gerektiği belirlenmiştir. Söz konusu otel işletmelerinde istihdam edilen 135 çalışana anket uygulanmış, hatalı ya da eksik olarak doldurulan 7 anket elenerek 128 anket analiz edilmiştir. Şubat-Nisan 2021 tarihinde gerçekleştirilen bu araştırma söz konusu otel işletmelerinde istihdam edilen bireylerin görüşleriyle ve anket yardımıyla toplanan verilerle sinırlandirılmaktadir.

\subsection{Veri Toplama Aracı ve Kullanılan Ölçekler}

Anket uygulaması 128 kişi üzerinde gerçekleştirilmiş olup, veriler birebir görüşmelerle toplanmıştır. Araştırma kapsamında kullanılan ankette demografik sorulara (9 adet), lider üye etkileşimi boyutlarını (12 ifade), örgütsel sağlık boyutlarını (20 ifade) ve whistleblowing boyutlarını (16 ifade) ölçen ifadelere yer verilmiştir.

Çalışanların algıladığı örgütsel sağlık düzeylerini ölçmek adına Lyden ve Klingele (2000) tarafından geliştirilen ve Türkçe'ye Doğan ve Bozkurt (2008) tarafından uyarlanan yapılan "Örgütsel Sağlık Ölçeğì"nden yararlanılmıştır. Bu ölçekte örgütsel sağlık "amaç birliği, itibar ve gelişim” ile "iletişim, moral ve performans" olmak üzere iki alt boyut olarak ele alınmıştır. Ölçek toplam 20 ifade içermektedir.

Lider ve üye arasındaki etkileşimi ölçebilmek adına Liden ve Maslyn'ce (1998) geliştirilmiş olan ve Türkçe'ye Baş ve diğerleri (2010) tarafından uyarlanan "Lider Üye Etkileşimi Ölçeği"nden (LMX-12)" yararlanılmıştır. Bu ölçekte lider üye etkileşimi "sadakat", "duygulanım", "profesyonel saygı" ve "katkı" olmak üzere dört alt boyut olarak ele alınmıştır. Ölçekte toplam 12 ifade yer almaktadir.

Çalışanların whistleblowing (açık etme) düzeylerini ölçmek adına Celep ve Konaklı (2012) tarafından geliştirilen “Açıı Etme (Whistleblowing) Ölçeğì”nden yararlanılmıştır. Bu ölçekte 
whistleblowing "içsel açık etme", "dışsal açık etme", "gizli açık etme" ve "destekçi açık etme" olmak üzere dört alt boyut olarak ele alınmıştır. Ölçekte toplam 16 ifade yer almaktadır.

Anket formu oluşturulurken kullanılan ölçekler 5'li Likert derecelemesi şeklindedir. Toplanan verilerin analiz edilmesi için SPSS programı kullanılmıştır. Söz konusu program yardımıyla araştırmaya dahil olan bireylerin demografik özelliklerini belirleyebilmek için frekans, değişkenler arası ilişkiler için korelasyon ve etkilerin tespiti için de regresyon analizinden yararlanılmıştır.

Ayrıca Mersin Üniversitesi Rektörlüğü Sosyal ve Beşeri Bilimler Etik Kurulunun 14/01/2021 tarihli toplantısında araştırma içerikleri ve anketleri incelenmiş ve etik açıdan uygunluğuna yönelik 03/02/2021-02 sayılı evrak tarafımıza iletilmiştir.

\subsection{Araştırma Modeli ve Hipotezler}

Örgütsel sağlık düzeylerinin lider üye etkileşimi ile whistleblowing eğilimlerini ve lider üye etkileşiminin de whistleblowing eğilimlerini olumlu olarak etkileyeceği düşünülmektedir. Gerçekleştirilen bu araştırmanın temel amacı, otel işletmelerinde çalışan bireylerin örgütsel sağlık algılarının whistleblowing ve lider üye etkileşimi üzerindeki etkisini belirlemektir.

Şekil 1: Araştırma Modeli

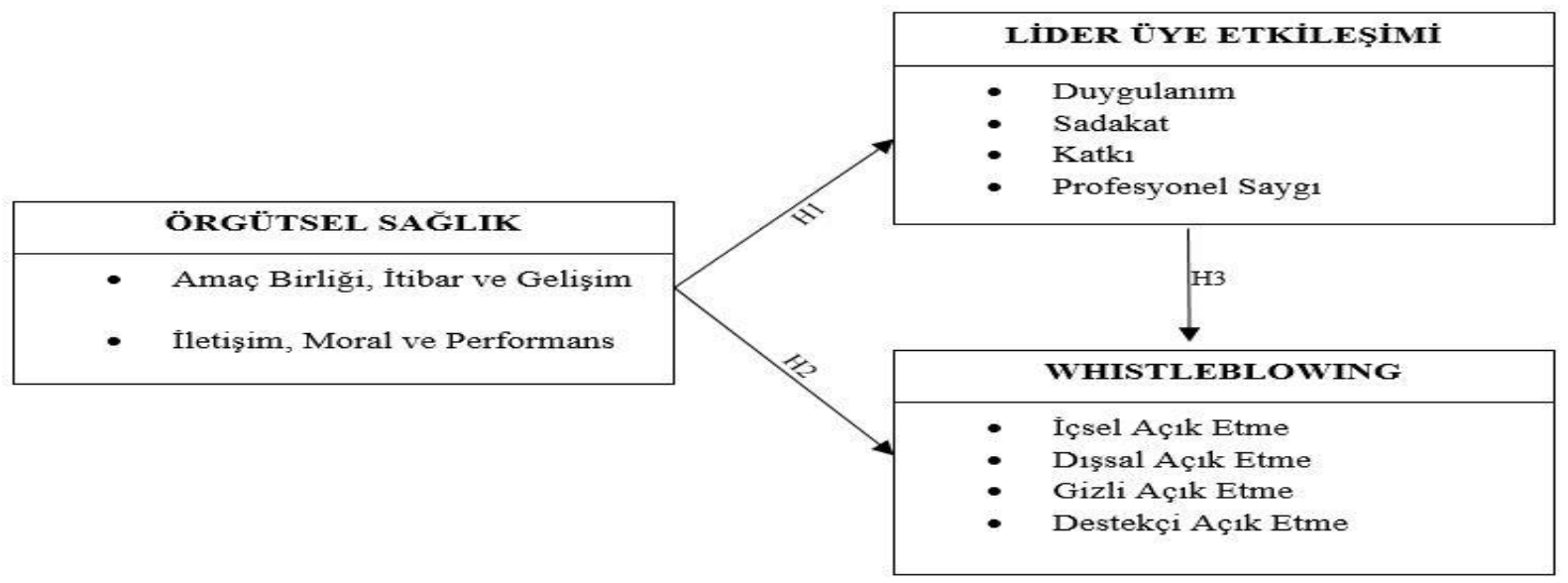

Araştırma modeli doğrultusunda aşağıdaki hipotezler oluşturulmuştur:

$\mathbf{H}_{1}$ : Örgütsel sağlık whistleblowingi pozitif yönde etkilemektedir.

$\boldsymbol{H}_{\text {Ia: }}$ Amaç birliği, itibar ve gelişim whistleblowing boyutlarını olumlu yönde etkilemektedir.

$\boldsymbol{H}_{1 b}$ : Iletişim, moral ve performansin whistleblowing boyutların olumlu yönde etkilemektedir.

$\mathbf{H}_{2}$ : Örgütsel sağlik lider üye etkileşimini pozitif yönde etkilemektedir.

$\boldsymbol{H}_{2 a}$ : Amaç birliği, itibar ve gelişim lider üye etkileşimi boyutlarını olumlu yönde etkilemektedir.

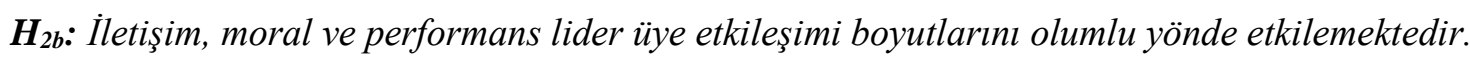

$\mathbf{H}_{3}$ : Lider üye etkileşimi whistleblowingi pozitif yönde etkilemektedir.

$\boldsymbol{H}_{3 a}$ : Duygulanım alt boyutu whistleblowing boyutlarını olumlu yönde etkilemektedir.

$\boldsymbol{H}_{3 b}$ : Sadakat alt boyutu whistleblowing boyutların olumlu yönde etkilemektedir.

$\boldsymbol{H}_{3 c}$ : Katkl alt boyutu whistleblowing boyutların olumlu yönde etkilemektedir.

$\boldsymbol{H}_{3 d:}$ Profesyonel sayg alt boyutu whistleblowing boyutların olumlu yönde etkilemektedir.

\section{ARAŞTIRMA BULGULARI}

\subsection{Demografik Bulgular}

Frekans analiz sonuçları incelendiğinde 128 adet katılımcının; \%32,8'i kadın, \%67,2'si erkek, $\% 42,2$ 'si bekar ve $\% 57,8$ 'i evli olup söz konusu çalışanların \%25,8'i 18-24 yaş aralığında, \%26,6's1 25-29 yaş aralığında, \%20,3'ü 30-35 yaş aralığında ve \%20,3'ü de 41 yaş ve üzerindedir. Eğitim 
durumu gözlemlendiğinde; \%42,2'si lise, \%21,1'i ön lisans, \%30,5'i lisans ve \%6,3'ü lisansüstü düzeyde eğitime sahiptir. Katılımcı bireylerin bağlı bulundukları yöneticilerle kaç yıldır çalıştıkları incelendiğinde; \%25,8'i 1 yıldan az, \%47,7'si 1-3 yıl, \%14,1'i 4-6 y1l aras1 ve \%12,5'i 7 yll ve daha uzun sürelerdir çalışmaktadır. Söz konusu yöneticilerin yaşları incelendiğinde; \%1,6's1 20-30 yaş aras1, \%37,5'i 31-40 yaş aras1, \%27,3'ü 41-50 yaş aras1 ve \%33,6's1 51 ve üzeri yaş düzeyinde olup \%18,8'i kadın, \%81,3'ü erkektir.

Tablo 1: Demografik Bulgular

\begin{tabular}{|c|c|c|c|c|c|}
\hline Demografik Özellikler & $(\mathbf{N})$ & $(\%)$ & Demografik Özellikler & $(\mathbf{N})$ & $(\%)$ \\
\hline Cinsiyet & & & Medeni Durum & & \\
\hline Kadin & 42 & 32,8 & Bekâr & 54 & 42,2 \\
\hline Erkek & 86 & 67,2 & Evli & 74 & 57,8 \\
\hline Toplam & 128 & 100 & Toplam & 128 & 100 \\
\hline $\begin{array}{l}\text { Yaş } \\
18-24 \text { aras1 } \\
25-29 \text { aras1 } \\
30-35 \text { aras1 } \\
36-40 \text { aras1 } \\
41 \text { ve üzeri }\end{array}$ & $\begin{array}{c}33 \\
34 \\
26 \\
9 \\
26\end{array}$ & $\begin{array}{c}25,8 \\
26,6 \\
20,3 \\
7,0 \\
20,3 \\
\end{array}$ & $\begin{array}{l}\text { Eğitim Durumu } \\
\text { Lise } \\
\text { Ön Lisans } \\
\text { Lisans } \\
\text { Lisansüstü }\end{array}$ & $\begin{array}{c}54 \\
27 \\
39 \\
8\end{array}$ & $\begin{array}{c}42,2 \\
21,1 \\
30,5 \\
6,3\end{array}$ \\
\hline Toplam & 128 & 100 & Toplam & 128 & 100 \\
\hline $\begin{array}{l}\text { Toplam Çalışma Süresi } \\
\text { (yıl) } \\
0-1 \\
1-3 \\
4-6 \\
7 \text { ve üzeri }\end{array}$ & $\begin{array}{l}19 \\
21 \\
24 \\
64\end{array}$ & $\begin{array}{l}14,8 \\
16,4 \\
18,8 \\
50,0\end{array}$ & $\begin{array}{l}\text { Kurumda Çalışma Süresi (yıl) } \\
0-1 \\
1-3 \\
4-6 \\
7 \text { ve üzeri }\end{array}$ & $\begin{array}{l}28 \\
38 \\
31 \\
31\end{array}$ & $\begin{array}{l}21,9 \\
29,7 \\
24,2 \\
24,2\end{array}$ \\
\hline Toplam & 128 & 100 & Toplam & 128 & 100 \\
\hline $\begin{array}{l}\text { Yöneticiniz ile Kaç Yıldır } \\
\text { Çalışıyorsunuz } \\
0-1 \\
1-3 \\
4-6 \\
7 \text { ve üzeri }\end{array}$ & $\begin{array}{l}33 \\
61 \\
18 \\
16 \\
\end{array}$ & $\begin{array}{l}25,8 \\
47,7 \\
14,1 \\
12,5 \\
\end{array}$ & $\begin{array}{l}\text { Yöneticinizin Yaşı } \\
20-30 \text { aras1 } \\
31-40 \text { arası } \\
41-50 \text { arası } \\
51 \text { ve üzeri }\end{array}$ & $\begin{array}{c}2 \\
48 \\
35 \\
43\end{array}$ & $\begin{array}{c}1,6 \\
37,5 \\
27,3 \\
33,6\end{array}$ \\
\hline Toplam & 128 & 100 & Toplam & 128 & 100 \\
\hline $\begin{array}{l}\text { Yöneticinizin Cinsiyeti } \\
\text { Kadın } \\
\text { Erkek }\end{array}$ & $\begin{array}{c}24 \\
104\end{array}$ & $\begin{array}{l}18,8 \\
81,3\end{array}$ & & & \\
\hline Toplam & 128 & 100 & & & \\
\hline
\end{tabular}

\subsection{Güvenilirlik ve Geçerlilik}

Araştırmada kullanılan ölçek maddelerinin yapısal geçerlilik analizi ve doğrulayıcı faktör analizlerinin yapılabilmesi adına ilk olarak elde edilen verilerin KMO katsayıları ve Barlett's Testi değerleri faktör analizine uygunluk açısından ele alınmıştır. Lider üye etkileşimi ölçeğinin KMO katsayısının \%63,7 (,637), Barlett's Küresellik Testi Ki-Kare değerinin ise 1692,559 olduğu tespit edilmiştir $(\mathrm{p}<0,05)$. Faktör analizi neticesinde lider üye etkileşimi ölçeğinin dört faktörlü bir yapıda olduğu ve faktörler tarafından toplam varyansın \%88,288'inin açıklandığı belirlenmiştir. Örgütsel sağlık ölçeğinin KMO katsayısının \%80,8 (,808), Barlett's Küresellik Testi Ki-Kare değerinin ise 1428,295 olduğu tespit edilmiştir $(\mathrm{p}<0,05)$. Faktör analizi neticesinde örgütsel sağllk ölçeğinin iki faktörlü bir yapıda olduğu ve faktörler tarafından toplam varyansın \%62,094'ünün açıklandığı belirlenmiştir. Son olarak whistleblowing ölçeğinin KMO katsayısının \%53,1 (,531), Barlett's Küresellik Testi Ki-Kare değerinin ise 2014,840 olduğu tespit edilmiştir $(p<0,05)$. Faktör analizi neticesinde whistleblowing ölçeğinin dört faktörlü bir yapıda olduğu ve faktörler tarafından toplam varyansın \%71,347'sinin açıklandığ 1 belirlenmiştir. Araştırma kapsamında kullanılan ölçeklere yönelik gerçekleştirilen doğrulayıcı faktör analizleri neticesinde ölçeklerin orijinallerinde yer aldığı gibi aynı boyutlar ortaya çıkmış olup, önermeler de aynı boyutlar altında toplanmaktadır.

Örgütsel sağlık, lider üye etkileşimi ve whistleblowing ölçeklerine yönelik Cronbach’s Alfa değerleri incelenerek iç tutarlılık düzeyleri Tablo 2'deki gibi bulunmuştur. 
Tablo 2: Güvenilirlik Analizi

\begin{tabular}{lcc}
\hline Kullanılan Ölçekler & İfade Sayısı & Alpha Katsayıları \\
\hline Örgütsel Sağlık & $\mathbf{2 0}$ & $\mathbf{8 1 7}$ \\
\hline Amaç Birliği, İtibar ve Gelişim & 9 &, 840 \\
\hline İletişim, Moral ve Performans & 11 &, 813 \\
\hline Lider Üye Etkileşimi & $\mathbf{1 2}$ & $\mathbf{7 7 6}$ \\
\hline Duygulanım & 3 &, 920 \\
\hline Sadakat & 3 &, 893 \\
\hline Katk1 & 3 &, 919 \\
\hline Profesyonel Saygı & 3 &, 966 \\
\hline Whistleblowing & $\mathbf{1 6}$ & $\mathbf{7 9 8}$ \\
\hline İçsel Açık Etme & 5 &, 715 \\
\hline Dişsal Açı Etme & 4 &, 786 \\
\hline Gizli Açık Etme & 3 &, 887 \\
\hline Destekçi Açıı Etme & 4 &, 805 \\
\hline
\end{tabular}

Tablo 2 incelendiğinde; örgütsel sağlik, lider üye etkileşimi ve whistleblowing alt boyutlarına yönelik katsayı değerlerinin (a) 0,70 düzeyinin oldukça yukarısında olduğu belirlenmiştir. Sosyal bilimler alanında 0,70 ve üzeri bir $(\alpha)$ değere sahip araştırma ölçekleri güvenilir bir yap1 şeklinde değerlendirilmektedir (Gürbüz \& Şahin, 2014).

\subsection{Korelasyon ve Regresyon Analizi Sonuçları}

Araştırma hipotezlerini test etmek amacıyla regresyon analizi gerçekleştirilmiştir. Regresyon analizi ve değişkenler arasındaki ilişkilerin hesaplanabilmesi adına gerçekleştirilecek korelasyon analizinden önce ölçek maddelerinin toplam değerleri madde sayılarına bölünmüş olup her bir alt ölçek veya faktör adına ortalama bir puan belirlenmiștir. Gerçekleștirilen söz konusu analizler bu puanlamalar üzerinden yapılmıştır. Elde edilen verilerin varyansların homojenliği ve normal dağılım gibi parametrik istatistik koşullarını ve regresyon analizine yönelik öncülleri taşıyıp taşımadığı incelenmiştir. Kolmogorov-Smirnov Testi ile verilerin normal dağıllım özelliği sergileyip sergilemediği, Levene testi ile de fark puanlarının homojenliği test edilmiştir. Söz konusu analizler neticesinde varyansların homojen bir yapıda olduğu ve verilerin de normal dağılım özelliği sergilediği tespit edilmiştir.

Bağımlı ve bağımsız değişkenlerin arasındaki ilişkinin varlığını belirleyebilmek adına korelasyon analizi gerçekleştirilmiştir (Tablo 3).

Tablo 3: Korelasyon Analizi

\begin{tabular}{|c|c|c|c|c|c|c|c|c|c|c|}
\hline & $\mathbf{1}$ & 2 & 3 & 4 & 5 & 6 & 7 & 8 & 9 & 10 \\
\hline $\begin{array}{l}\text { Amaç Birliği, İtibar } \\
\text { ve Gelisim (1) }\end{array}$ & 1 & & & & & & & & & \\
\hline \multirow{2}{*}{$\begin{array}{l}\text { İletişim, Moral ve } \\
\text { Performans (2) }\end{array}$} &, $165 * *$ & 1 & & & & & & & & \\
\hline &, 001 & & & & & & & & & \\
\hline \multirow{2}{*}{ İçsel Açık Etme (3) } &, $128 * *$ & $101 *$ & 1 & & & & & & & \\
\hline & ,001 & ,035 & & & & & & & & \\
\hline \multirow{2}{*}{$\begin{array}{l}\text { Dışsal Açık Etme } \\
\text { (4) }\end{array}$} &, $156^{* *}$ & ,098 & $239^{* * *}$ & 1 & & & & & & \\
\hline & ,001 &, 061 & ,007 & & & & & & & \\
\hline \multirow{2}{*}{ Gizli Açık Etme (5) } & $349^{* * *}$ & ,088* & ,033 & $285^{* *}$ & 1 & & & & & \\
\hline & ,000 & ,021 & ,713 & ,001 & & & & & & \\
\hline \multirow{2}{*}{$\begin{array}{l}\text { Destekçi Açık Etme } \\
\text { (6) }\end{array}$} &, $132 *$ & ,130* & $499^{* *}$ & ,198* &, $101 *$ & 1 & & & & \\
\hline & ,024 &, 045 & ,000 &, 025 &, 025 & & & & & \\
\hline \multirow{2}{*}{ Duygulanım (7) } &, $130 * *$ &, $210^{*}$ &, $174^{*}$ &, 152 &, $043 *$ &, $077 *$ & 1 & & & \\
\hline &, 000 &, 017 & ,049 &, 086 &, 042 &, 041 & & & & \\
\hline \multirow{2}{*}{ Sadakat (8) } &, $119 * *$ & $203^{*}$ & $180^{*}$ & ,267* &, $192^{*}$ & $178^{*}$ & $214^{*}$ & 1 & & \\
\hline & ,001 &, 021 &, 027 &, 027 &, 030 & ,044 &, 015 & & & \\
\hline \multirow{2}{*}{ Katkı (9) } &, $261 * *$ & $133^{*}$ &, $141 *$ &, $177^{*}$ &, $432^{* * *}$ & $130 * *$ & $137 *$ & $327^{* *}$ & 1 & \\
\hline &, 000 & ,012 & ,046 & ,046 &, 000 & ,001 & ,032 &, 000 & & \\
\hline \multirow{2}{*}{$\begin{array}{l}\text { Profesyonel Saygı } \\
\text { (10) }\end{array}$} &, $223 * *$ & $159 *$ &, $163^{*}$ &, $143^{*}$ &, $144 *$ &, $284^{* *}$ & $119^{*}$ &, $216^{*}$ & ,249* & 1 \\
\hline &, 002 & ,036 & ,031 &, 017 &, 016 &, 001 &, 035 &, 014 &, 030 & \\
\hline
\end{tabular}


Örgütsel sağl1k, lider üye etkileşimi ve whistleblowing arasında pozitif yönlü anlamlı ilişkiler gözlenmiştir. Araştırma hipotezleri doğrultusunda bağımsız değişkenlerin bağımlı değişkenler üzerindeki etkisini incelemek üzere regresyon analizi yapılmıştır.

Tablo 4: Örgütsel Sağllğın Whistleblowing Üzerindeki Etkisi

\begin{tabular}{lc}
\hline & BAĞIMLI DEĞISSKEN \\
\hline BAĞIMSIZ DEĞíşKEN & Whistleblowing \\
\hline $\mathbf{R}^{2}$ &, 114 \\
\hline $\mathbf{F}$ & 24,247 \\
\hline Örgütsel Sağlık & $\boldsymbol{\beta}, 394$ \\
\hline
\end{tabular}

Yapılan regresyon analizi sonuçlarına göre; whistleblowingde meydana gelen değişimin $\% 11,4$ 'ünün $\left(\mathrm{R}^{2}=0,114\right)$ bağımsız değişken örgütsel sağlık tarafindan açıklandığı gözlemlenmektedir. Bulgular neticesinde, whistleblowingin istatistiksel olarak anlamlı düzeyde örgütsel sağlıktan etkilendiği $(\mathrm{F}=24,247)$, “ $\beta$ ” değerlerine göre de örgütsel sağl1kta görülen bir birimlik artışın whistleblowing üzerinde 0,394 birimlik bir artışa sebebiyet verdiği belirlenmiştir $(\mathrm{p}<0,05) . \mathrm{Bu}$ bulgular neticesinde, "Örgütsel sağllk whistleblowingi pozitif yönde etkilemektedir" hipoteziyle test edilmeye çalışılan $\mathrm{H}_{1}$ kabul edilmiştir.

Tablo 5: Örgütsel Sağlık Alt Boyutlarının Whistleblowing Alt Boyutlarına Etkisi

\begin{tabular}{lcccc}
\hline & \multicolumn{2}{c}{ BAĞIMLI DEĞİ̧̧KENLER } & & \\
\hline BAĞIMSIZ DEĞIŞKEN & İçsel Açık Etme & Dışsal Açık Etme & Gizli Açık Etme & Destekçi Açık Etme \\
\hline $\mathbf{R}^{\mathbf{2}}$ &, 015 &, 026 &, 115 &, 040 \\
\hline $\mathbf{F}$ & 4,238 & 6,124 & 17,434 & 8,225 \\
\hline Amaç birliği, İtibar ve & $\boldsymbol{\beta}, 144$ & $\boldsymbol{\beta}, 156$ & $\boldsymbol{\beta}, 349$ & $\mathbf{\beta}, 232$ \\
Gelişim & $\mathbf{p}, 017$ & $\mathbf{p}, 040$ & $\mathbf{p}, 000$ & $\mathbf{p}, 038$ \\
\hline $\mathbf{R}^{\mathbf{2}}$ &, 051 &, 048 &, 066 &, 039 \\
\hline $\mathbf{F}$ & 10,307 & 9,992 & 11,294 & 7,154 \\
\hline Iletişim, Moral ve & $\boldsymbol{\beta}, 194$ & $\boldsymbol{\beta}, 273$ & $\boldsymbol{\beta}, 245$ & $\mathbf{\beta}, 130$ \\
Performans & $\mathbf{p}, 025$ & $\mathbf{p}, 011$ & $\mathbf{p}, 009$ & $\mathbf{p}, 045$ \\
\hline
\end{tabular}

Yapılan regresyon analizinde; whistleblowing alt boyutları olan içsel açık etmedeki değişimin $\% 1,5$ 'inin $\left(\mathrm{R}^{2}=0,015\right)$; dışsal açık etmedeki değişimin $\% 2,6$ 'sının $\left(\mathrm{R}^{2}=0,026\right)$; gizli açık etmedeki değişimin \%11,5'inin $\left(\mathrm{R}^{2}=0,115\right)$ ve destekçi açık etmedeki değişimin \%4,0'ünün $\left(\mathrm{R}^{2}=0,040\right)$ bağımsız değişken amaç birliği, itibar ve gelişim tarafindan açıklandığı gözlemlenmektedir. Bulgular neticesinde, whistleblowing boyutlarının istatistiksel olarak anlamlı düzeyde amaç birliği, itibar ve gelişimden etkilendiği $(\mathrm{F}=4,238 ; 6,124 ; 17,434 ; 8,225)$, “ $\beta$ ” değerlerine göre de amaç birliği, itibar ve gelişimdeki bir birimlik artışın içsel açık etme üzerinde 0,144 ; dışsal açık etme üzerinde 0,156 ; gizli açık etme üzerinde 0,349 ve destekçi açı etme üzerinde 0,232 birimlik bir artışa sebebiyet verdiği tespit edilmiştir $(\mathrm{p}<0,05)$. Bu bulgular neticesinde, "Amaç birliği, itibar ve gelişim whistleblowing boyutlarını olumlu yönde etkilemektedir" hipoteziyle test edilmeye çalışılan $\mathrm{H}_{1 \mathrm{a}}$ kabul edilmiştir.

Yapılan regresyon analizi sonuçlarına göre; whistleblowing alt boyutları olan içsel açık etmedeki değişimin $\% 5,1$ 'inin $\left(\mathrm{R}^{2}=0,051\right)$; dışsal açık etmedeki değişimin $\% 4,8$ 'inin $\left(\mathrm{R}^{2}=0,048\right)$; gizli açık etmedeki değişimin \%6,6'sının $\left(\mathrm{R}^{2}=0,066\right)$ ve destekçi açık etmedeki değişimin \%3,9'unun $\left(\mathrm{R}^{2}=0,039\right)$ bağımsız değişken iletişim, moral ve performans tarafindan açıklandığı gözlemlenmektedir. Bulgular neticesinde, whistleblowing boyutlarının istatistiksel olarak anlamlı düzeyde iletişim, moral ve performanstan etkilendiği $(\mathrm{F}=10,307 ; 9,992 ; 11,294 ; 7,154)$, " $\beta$ " değerlerine göre de iletişim, moral ve performanstaki bir birimlik artışın içsel açık etme üzerinde 0,194; dişsal açık etme üzerinde 0,273; gizli açık etme üzerinde 0,245 ve destekçi açık etme üzerinde 0,130 birimlik bir artışa sebebiyet verdiği tespit edilmiştir $(\mathrm{p}<0,05)$. Bu bulgular neticesinde, "Illetişim, moral ve performans whistleblowing boyutlarl olumlu yönde etkilemektedir" hipoteziyle test edilmeye çalışılan $\mathrm{H}_{1 \mathrm{~b}}$ kabul edilmiştir. 
Tablo 6: Örgütsel Sağlığın Lider Üye Etkileşimi Üzerindeki Etkisi

\begin{tabular}{lc}
\hline & BAĞIMLI DEĞIŞKEN \\
\hline BAĞIMSIZ DEĞIŞKEN & Lider Üye Etkileşimi \\
\hline $\mathbf{R}^{2}$ &, 071 \\
\hline F & 12,894 \\
\hline \multirow{2}{*}{ Örgütsel Sağlık } & $\boldsymbol{\beta}, 242$ \\
\hline
\end{tabular}

Yapılan regresyon analizinde lider üye etkileşimindeki değişimin $\% 7,1$ 'inin $\left(\mathrm{R}^{2}=0,071\right)$ bağımsız değişken örgütsel sağlık tarafından açıklandığı gözlemlenmektedir. Bulgular neticesinde, lider üye etkileşiminin istatistiksel olarak anlamlı düzeyde örgütsel sağllktan etkilendiği $(F=12,894)$, " $\beta$ " değerlerine göre de örgütsel sağlıkta meydana gelen bir birimlik artışın lider üye etkileşimi üzerinde 0,242 birimlik bir artışa sebebiyet verdiği belirlenmiştir $(\mathrm{p}<0,05)$. Bu bulgular neticesinde, "Örgütsel sağlık lider üye etkileşimini pozitif yönde etkilemektedir" hipoteziyle test edilmeye çalış1lan $\mathrm{H}_{2}$ kabul edilmiştir.

Tablo 7: Örgütsel Sağlık Alt Boyutlarının Lider Üye Etkileşimi Alt Boyutlarına Etkisi

\begin{tabular}{|c|c|c|c|c|}
\hline \multicolumn{5}{|c|}{ BAĞIMLI DEĞİŞKENLER } \\
\hline BAĞIMSIZ DEĞİŞKEN & Duygulanım & Sadakat & Katkı & Profesyonel Saygı \\
\hline $\mathbf{R}^{2}$ & 032 &, 006 &, 024 & ,028 \\
\hline $\mathbf{F}$ & 9,549 & 1,808 & 8,466 & 9,292 \\
\hline \multirow{2}{*}{$\begin{array}{l}\text { Amaç birliği, İtibar ve } \\
\text { Gelişim }\end{array}$} & $\boldsymbol{\beta}, 130$ & $\boldsymbol{\beta}, 119$ & $\boldsymbol{\beta}, 161$ & $\boldsymbol{\beta}, 178$ \\
\hline & $\mathbf{p , 0 2 1}$ & p, 018 & $\mathbf{p}, 006$ & $\mathbf{p}, 020$ \\
\hline $\mathbf{R}^{2}$ &, 029 &, 034 &, 048 &, 039 \\
\hline $\mathbf{F}$ & 5,819 & 5,437 & 11,347 & 9,608 \\
\hline \multirow{2}{*}{$\begin{array}{l}\text { İletişim, Moral ve } \\
\text { Performans }\end{array}$} & $\boldsymbol{\beta}, 210$ & $\boldsymbol{\beta}, 203$ & $\boldsymbol{\beta}, 331$ & $\boldsymbol{\beta}, 182$ \\
\hline & $\mathbf{p}, 017$ & $\mathbf{p}, 021$ & $\mathbf{p}, 001$ & $\mathbf{p}, 004$ \\
\hline
\end{tabular}

Yapılan regresyon analizi sonuçlarına göre; lider üye etkileşimi alt boyutlanı olan duygulanımdaki değişimin \%3,2'sinin $\left(\mathrm{R}^{2}=0,032\right)$; sadakatteki değişimin $\% 0,6$ 'sının $\left(\mathrm{R}^{2}=0,006\right)$; katkıdaki değişimin $\% 2,4$ 'inin $\left(\mathrm{R}^{2}=0,024\right)$ ve profesyonel saygıdaki değişimin $\% 2,8$ 'ünün $\left(\mathrm{R}^{2}=0,028\right)$ bağımsız değişken amaç birliği, itibar ve gelişim tarafindan açıklandığı gözlemlenmektedir. Bulgular neticesinde, lider üye etkileşimi boyutları istatistiksel olarak anlamlı düzeyde amaç birliği, itibar ve gelişimden etkilenmekte (sırasıyla $\mathrm{F}=9,549 ; 1,808 ; 8,466 ; 9,292$ ), " $\beta$ ” değerlerine göre de amaç birliği, itibar ve gelişimdeki bir birimlik artışın duygulanım üzerinde 0,130 , sadakat üzerinde 0,119 , katk1 üzerinde 0,161 ve profesyonel saygı üzerinde 0,178 birimlik bir artışa sebebiyet verdiği belirlenmiştir $(\mathrm{p}<0,05)$. Bu sonuçlar doğrultusunda, "Amaç birliği, itibar ve gelişim, lider üye etkileşimi boyutlarını olumlu yönde etkilemektedir" hipoteziyle test edilmeye çalış1lan $\mathrm{H}_{2 \mathrm{a}}$ kabul edilmiştir.

Yapılan regresyon analizi sonuçlarına göre; lider üye etkileşimi alt boyutları olan duygulanımdaki değişimin $\% 2,9^{\prime}$ unun $\left(\mathrm{R}^{2}=0,029\right)$; sadakatteki değişimin $\% 3,4$ 'ünün $\left(\mathrm{R}^{2}=0,034\right)$; katkıdaki değişimin $\% 4,8^{\prime}$ inin $\left(\mathrm{R}^{2}=0,048\right)$ ve profesyonel saygıdaki değişimin $\% 3,9$ 'unun $\left(\mathrm{R}^{2}=0,039\right)$ bağımsız değişken iletişim, moral ve performans tarafindan açıklandığı gözlemlenmektedir. Bulgular neticesinde, lider üye etkileşimi boyutları istatistiksel olarak anlamlı düzeyde iletişim, moral ve performanstan etkilenmekte (sırasiyla $\mathrm{F}=5,819 ; 5,437 ; 11,347 ; 9,608$ ), " $\beta$ " değerlerine göre de iletişim, moral ve performanstaki bir birimlik artışın duygulanım üzerinde 0,210 , sadakat üzerinde 0,203 , katkı üzerinde 0,331 ve profesyonel sayg1 üzerinde 0,182 birimlik bir artışa sebebiyet verdiği belirlenmiştir $(\mathrm{p}<0,05)$. Bu sonuçlar doğrultusunda, "Illetişim, moral ve performans, lider üye etkileşimi boyutlarını olumlu yönde etkilemektedir" hipoteziyle test edilmeye çalışılan $\mathrm{H}_{2 \mathrm{~b}}$ kabul edilmiştir. 
Tablo 8: Lider Üye Etkileşiminin Whistleblowing Üzerindeki Etkisi

\begin{tabular}{lc}
\hline & BAĞIMLI DEĞİŞKEN \\
\hline BAĞIMSIZ DEĞIŞKEN & Whistleblowing \\
\hline $\mathbf{R}^{2}$ &, 057 \\
\hline $\mathbf{F}$ & 10,192 \\
\hline \multirow{2}{*}{ Lider Üye Etkileşimi } & $\boldsymbol{\beta}, 449$ \\
\cline { 2 - 2 } & $\mathbf{p}, 001$ \\
\hline
\end{tabular}

Yapılan regresyon analizi sonuçlarına göre; whistleblowingdeki değişimin \%5,7'sinin $\left(\mathrm{R}^{2}=0,057\right)$ bağımsız değişken lider üye etkileşimi tarafından açıklandığı gözlemlenmektedir. Bulgular neticesinde whistleblowing istatistiksel olarak anlamlı düzeyde lider üye etkileşiminden etkilenmekte $(\mathrm{F}=10,192)$, " $\beta$ " değerlerine göre de lider üye etkileşiminde meydana gelen bir birimlik artışın whistleblowing üzerinde 0,449 birimlik bir artışa sebebiyet verdiği belirlenmiştir $(p<0,05) . \mathrm{Bu}$ bulgular neticesinde, "Lider üye etkileşimi whistleblowingi pozitif yönde etkilemektedir" hipoteziyle test edilmeye çalışılan $\mathrm{H}_{3}$ kabul edilmiştir.

Tablo 9: Lider Üye Etkileşimi Alt Boyutlarının Whistleblowing Alt Boyutlarına Etkisi

\begin{tabular}{|c|c|c|c|c|}
\hline \multicolumn{5}{|c|}{ BAĞIMLI DEĞİŞKENLER } \\
\hline BAĞIMSIZ DEĞİŞKEN & İçsel Açık Etme & Dışsal Açık Etme & Gizli Açık Etme & Destekçi Açık Etme \\
\hline $\mathbf{R}^{2}$ &, 023 &, 015 & ,062 &, 047 \\
\hline $\mathbf{F}$ & 3,941 & 2,990 & 15,481 & 11,294 \\
\hline \multirow{2}{*}{ Duygulanım } & $\boldsymbol{\beta}, 174$ & $\boldsymbol{\beta}, 152$ & $\boldsymbol{\beta}, 479$ & $\boldsymbol{\beta}, 322$ \\
\hline & p,029 & p, 026 & p, 011 & p ,028 \\
\hline $\mathbf{R}^{2}$ &, 026 &, 037 &, 029 &, 024 \\
\hline $\mathbf{F}$ & 4,681 & 8,103 & 4,814 & 4,143 \\
\hline \multirow{2}{*}{ Sadakat } & $\boldsymbol{\beta}, 188$ & $\boldsymbol{\beta}, 245$ & $\boldsymbol{\beta}, 192$ & $\boldsymbol{\beta}, 178$ \\
\hline & $\mathbf{p}, 022$ & p $, 0,15$ & $\mathbf{p}, 030$ & p,, 023 \\
\hline $\mathbf{R}^{2}$ &, 034 &, 023 &, 180 &, 007 \\
\hline $\mathbf{F}$ & 7,212 & 4,052 & 12,095 & 1,276 \\
\hline \multirow{2}{*}{ Katkı } & $\boldsymbol{\beta}, 241$ & $\boldsymbol{\beta}, 177$ & $\boldsymbol{\beta}, 432$ & $\boldsymbol{\beta}, 024$ \\
\hline & p ,014 & p,046 & $\mathbf{p}, 000$ & p,061 \\
\hline $\mathbf{R}^{2}$ &, 027 &, 021 &, 013 &, 017 \\
\hline $\mathbf{F}$ & 4,453 & 3,638 & 2,657 & 3,153 \\
\hline \multirow{2}{*}{ Profesyonel Saygı } & $\boldsymbol{\beta}, 193$ & $\boldsymbol{\beta}, 143$ & $\boldsymbol{\beta}-, 144$ & $\boldsymbol{\beta}-, 281$ \\
\hline & $\mathbf{p}, 021$ & p,017 & $\mathbf{p}, 106$ & $\mathbf{p}, 163$ \\
\hline
\end{tabular}

Yapılan regresyon analizi sonuçlarına göre; whistleblowing alt boyutları olan içsel açık etmedeki değişimin $\% 2,3$ 'ünün $\left(\mathrm{R}^{2}=0,023\right)$; dışsal açık etmedeki değişimin $\% 1,5$ 'inin $\left(\mathrm{R}^{2}=0,015\right)$; gizli açık etmedeki değişimin $\% 6,2$ 'sinin $\left(\mathrm{R}^{2}=0,62\right)$ ve destekçi açık etmedeki değişimin \%4,7'sinin $\left(\mathrm{R}^{2}=0,047\right)$ bağımsız değişken duygulanım tarafindan açıklandığı gözlemlenmektedir. Bulgular neticesinde, whistleblowing boyutları istatistiksel olarak anlamlı düzeyde duygulanımdan etkilenmekte (sırasıyla $\mathrm{F}=3,941 ; 2,990 ; 15,481 ; 11,294)$ ) " $\beta$ ” değerlerine göre de duygulanımdaki bir birimlik artışın içsel açık etme üzerinde 0,174 ; dışsal açık etme üzerinde 0,152 ; gizli açık etme üzerinde 0,479 ve destekçi açı etme üzerinde 0,322 birimlik bir artışa sebebiyet verdiği tespit edilmiştir $(\mathrm{p}<0,05)$. Bu bulgular neticesinde, "Duygulanım whistleblowing boyutlarını olumlu yönde etkilemektedir" hipoteziyle test edilmeye çalış1lan $\mathrm{H}_{3 a}$ kabul edilmiştir.

Yapılan regresyon analizi sonuçlarına göre; whistleblowing alt boyutları olan içsel açık etmedeki değişimin $\% 2,6$ ' sının $\left(\mathrm{R}^{2}=0,026\right)$; dişsal açık etmedeki değişimin $\% 3,7$ 'sinin $\left(\mathrm{R}^{2}=0,037\right)$; gizli açık etmedeki değişimin \%2,9'unun $\left(\mathrm{R}^{2}=0,029\right)$ ve destekçi açık etmedeki değişimin \%2,4'ünün $\left(\mathrm{R}^{2}=0,024\right)$ bağımsız değişken sadakat tarafından açıklandığı gözlemlenmektedir. Bulgular neticesinde, whistleblowing boyutları istatistiksel olarak anlamlı düzeyde sadakatten etkilenmekte (sırasıyla $\mathrm{F}=4,681 ; 8,103 ; 4,814 ; 4,143$ ), " $\beta$ " değerlerine göre de sadakatteki bir birimlik artışın içsel açık etme üzerinde 0,188 ; dışsal açık etme üzerinde 0,245 ; gizli açık etme üzerinde 0,192 ve destekçi açık etme üzerinde 0,178 birimlik bir artışa sebebiyet verdiği tespit edilmiştir $(\mathrm{p}<0,05)$. Bu bulgular neticesinde, "Sadakat whistleblowing boyutlarını olumlu yönde etkilemektedir" hipoteziyle test edilmeye çalış1lan $\mathrm{H}_{3 \mathrm{~b}}$ kabul edilmiştir.

Yapılan regresyon analizi sonuçlarına göre; whistleblowing alt boyutları olan içsel açık etmedeki değişimin $\% 3,4$ 'ünün $\left(\mathrm{R}^{2}=0,034\right)$; dişsal açık etmedeki değişimin $\% 2,3$ 'ünün $\left(\mathrm{R}^{2}=0,023\right)$; 
gizli açık etmedeki değişimin $\% 18$ 'inin $\left(\mathrm{R}^{2}=0,180\right)$ ve destekçi açı etmedeki değiş̧imin \%0,7'inin $\left(\mathrm{R}^{2}=0,007\right)$ bağımsız değişken katkı tarafından açıklandığı gözlemlenmektedir. Bulgular neticesinde, whistleblowing boyutları istatistiksel olarak anlamlı düzeyde katkıdan etkilenmekte (sirasıla $\mathrm{F}=$ 7,212; 4,052; 12,095), sadece whistleblowing alt boyutu olan destekçi açık etme bağımsız değişken olan katkı tarafından etkilenmemektedir ( $\mathrm{F}=1,276$; $\mathrm{p}$ : ,061). " $\beta$ ” değerlerine göre de katkıdaki bir birimlik artışın içsel açık etme üzerinde 0,241; dışsal açık etme üzerinde 0,177; gizli açık etme üzerinde 0,432 birimlik bir artışa sebebiyet vermektedir $(\mathrm{p}<0,05)$. Bu bulgular neticesinde, "Katkr whistleblowing boyutlarını olumlu yönde etkilemektedir" hipoteziyle test edilmeye çalış1lan $\mathrm{H}_{3 \mathrm{c}}$ kısmen kabul edilmiştir.

Yapılan regresyon analizi sonuçlarına göre; whistleblowing alt boyutları olan içsel açık etmedeki değişimin \%2,7'sinin $\left(\mathrm{R}^{2}=0,027\right)$; dişsal açık etmedeki değişimin $\% 2,1$ 'inin $\left(\mathrm{R}^{2}=0,021\right)$; gizli açık etmedeki değişimin \%1,3'ünün $\left(\mathrm{R}^{2}=0,013\right)$ ve destekçi açık etmedeki değişimin $\% 1,7$ 'sinin $\left(\mathrm{R}^{2}=0,017\right)$ bağımsız değişken profesyonel saygı tarafindan açıklandığı gözlemlenmektedir. Bulgular neticesinde, whistleblowing boyutları istatistiksel olarak anlamlı düzeyde profesyonel saygıdan etkilenmektedir (sırasıyla $\mathrm{F}=4,453 ; 3,638$ ). Sadece whistleblowing alt boyutu olan gizli açık etme ve destekçi açık etme bağımsız değişken olan profesyonel saygı tarafindan etkilenmemektedir (sırasıyla $\mathrm{F}=2,657 ; 3,153 ; \mathrm{p}:$,106; ,163). " $\beta$ " değerlerine göre de sadakatteki bir birimlik artışın içsel açık etme üzerinde 0,193 ; dışsal açık etme üzerinde 0,143 birimlik bir artışa sebebiyet vermektedir $(\mathrm{p}<0,05)$. Bu bulgular neticesinde, "Profesyonel saygı whistleblowing boyutların olumlu yönde etkilemektedir" hipoteziyle test edilmeye çalışılan $\mathrm{H}_{3 \mathrm{~d}}$ kısmen kabul edilmiştir.

\section{SONUC VE ÖNERILER}

Küreselleşmenin etkilerini arttırarak gösterdiği bugünün endüstriyel iş dünyasında kamu ya da özel sektör fark etmeksizin bütün örgütler adına çevresel unsurların oldukça belirsiz ve hareketli olduğu, teknolojik, politik, sosyal, ekonomik, kültürel ve siyasal gelişme ve değişimlerin çok hızlı yaşandığı bir yapı süregelmektedir. Söz konusu bu yapılar, turizm sektöründe yer alan örgütlerin de yapılarında sürekli bir gelişim ve değişimi mecbur kılmaktadır.

Turizm sektöründe yer alan işletmeler, içerisinde yer aldıkları çevrede gerçekleştirdikleri faaliyetlerin niteliklerinden dolayı, çeşitli paydaşlarla etkileşim ve iletişim içerisindedirler. Bu örgütler sürdürülebilir bir yapı kurabilmek adına sürekli gelişim felsefesini benimsemeli, örgüt içerisinde meydana gelen çatışmaları örgütsel amaçlar doğrultusunda çözüme kavuşturabilmeli, insan kaynaklarını ve kullandıkları teknolojiyi iyi yönetmeli ve kaliteli ve etkin bir hizmet anlayışı geliştirmelidir. Tüm bunlar ise ancak sağlıklı bir örgüt yapısının kurulması ve lider üye arasındaki etkileşimin sağlanmasıyla gerçekleşebilmektedir. Daha hassas ve kompleks bir hizmetin sunulduğu turizm örgütlerinde; teknolojinin hızlı değişim ve gelişimi, hizmetlerin karmaşık ve büyük takımlar halinde koordineli bir şekilde sunulması mecburiyeti ile taleplerin belirsizliği ve tutarsızlığı gibi etmenler lider ve astları arasındaki etkileşimi daha da önemli kılmaktadır. Bu sebeple; turizm örgütlerinde liderlerin astları ile anlayış, saygı, güven, destek unsurlarına dayalı etkileşim kurması kaçınılmaz bir gerçek halini almaktadır. Bununla birlikte, sağlıklı bir örgüt yapısı ve lider ile astı arasında kurulan doğru etkileşim; çalışanların verimlilik, etkinlik, performans, iş tatmini ve erdemli açık etme (whistleblowing) davranışlarını olumlu yönde etkilerken, tükenmişlik, sinizm, atalet, işten ayrılma niyeti gibi unsurları da negatif yönde etkilemektedir (Dulebohn vd., 2012: 1717; Kang \& Stewart, 2007: 533).

Günümüz iş dünyasında küreselleşmenin yarattığı belirsiz ve dinamik bir yapıya sahip olan çevreler, örgütler üzerinde ciddi baskı yaratmakta, bu yüzden de örgütler sürdürülebilir rekabetçi avantajı elde ederek piyasada yaşamlarını sürdürebilmek adına çeşitli yönetim stratejileri uygulamaktadır. $\mathrm{Bu}$ stratejilerin başında çalışanların örgütsel hedefler doğrultusunda güdülenmelerini sağlayacak faaliyetler, biçimsel rol davranışlarının dışında kalan ve çalışan davranışlarına yön veren norm ve etik kurallar yer almaktadır. İlgili alan yazında iş etiği olarak da adlandırılan bu norm ve kurallar aynı zamanda bu araştırmanın bir değişkeni de olan whistleblowing olgusunu gündeme getirmiştir. Örgütler adına çok ciddi zararlara sebebiyet verebilecek ahlak ve etik dışı davranışların örgüt içerisinde ya da örgüt dışındaki birey/kurum/yetkililere bildirilmesi olarak ifade edilen whistleblowing her ne kadar olumsuz nitelikli bir olgu olarak düşünülse de toplumsal sorumluluk ve iş 
etiği ve ahlakı açısından son derece önemli bir kavramdır. Doğru şekilde uygulandığı takdirde önemli kazanımları olan whistleblowing eylemi örgüt içerisinde teşvik edilmeli, söz konusu ahlak ve etik dışı davranışların önlenmesinde ya da ortaya çıkartılmasındaki sorumluluk duygusu çalışanlara net bir şekilde aktarılmalıdır (Ayar, 2020: 29).

$\mathrm{Bu}$ araştırmada otel işletmelerinde çalışan bireylerin örgütsel sağlık algılarının whistleblowing ve lider üye etkileşimine yönelik etkilerinin tespit edilmesi amaçlanmış, bu amaç doğrultusunda Doğu Akdeniz bölgesinde faaliyette bulunan beş yıldızlı iki otel işletmesinde görev yapan 128 bireye anket uygulanmıştır. Örgütsel sağlık, lider üye etkileşimi ve whistleblowingi ölçebilmek adına 48 ifade ve üç ölçekten meydana gelen güvenirliliği ve geçerliliği kanıtlanmış anketten yararlanılmıştır.

Araştırma sonuçlarına göre, örgütsel sağlık, lider üye etkileşimi ve whistleblowing arasında pozitif yönlü anlamlı ilişki gözlemlenmiştir. Ayrıca örgütsel sağlık, lider üye etkileşimi ve whistleblowing ölçekleri alt boyutlarının da kendi arasında pozitif ve anlamlı ilişkiler geliştirdiği tespit edilmiştir.

Regresyon analizi neticesinde elde edilen bulgulara göre; whistleblowing örgütsel sağliktan anlamlı düzeyde etkilenmektedir. Dolayısıyla; "Örgütsel sağllk whistleblowingi pozitif yönde etkilemektedir" olarak ifade edilen $\mathrm{H}_{1}$ kabul edilmiştir. Whistleblowing alt boyutları olan "içsel açık etme", "dışsal açık etme", "gizli açık etme" ve "destekçi açık etme" anlamlı düzeyde örgütsel sağlığın "amaç birliği, itibar ve gelişim" ve "iletişim, moral ve performans" alt boyutlarınca etkilenmektedir. $\mathrm{Bu}$ bulgular neticesinde, "Amaç birliği, itibar ve gelişim whistleblowing boyutlarını olumlu yönde etkilemektedir" olarak ifade edilen $\mathrm{H}_{1 \mathrm{a}}$ ve "Iletişim, moral ve performans whistleblowing boyutların olumlu yönde etkilemektedir" olarak ifade edilen $\mathrm{H}_{1 \mathrm{~b}}$ kabul edilmiştir.

Regresyon analizi neticesinde elde edilen bulgulara göre; lider üye etkileşimi anlamlı düzeyde örgütsel sağlıktan etkilenmektedir. Dolayısıyla, "Örgütsel sağllk lider üye etkileşimini pozitif yönde etkilemektedir" olarak ifade edilen $\mathrm{H}_{2}$ kabul edilmiştir. Lider üye etkileşiminin "duygulanım", "sadakat", "katkı", ve "profesyonel saygı" alt boyutları anlamlı düzeyde örgütsel sağlığın "amaç birliği, itibar ve gelişim" ve "iletişim, moral ve performans" alt boyutlarınca etkilenmektedir. Bu bulgular neticesinde, "Amaç birliği, itibar ve gelişim, lider üye etkileşimi boyutlarını olumlu yönde etkilemektedir" olarak ifade edilen $\mathrm{H}_{2 \mathrm{a}}$ ve "İletişim, moral ve performans, lider üye etkileşimi boyutlarını olumlu yönde etkilemektedir" olarak ifade edilen $\mathrm{H}_{2 \mathrm{~b}}$ kabul edilmiştir.

Regresyon analizi neticesinde elde edilen bulgulara göre; whistleblowing anlamlı düzeyde lider üye etkileşiminden etkilenmektedir. Dolayısıyla, "Lider üye etkileşimi whistleblowingi pozitif yönde etkilemektedir" olarak ifade edilen $\mathrm{H}_{3}$ kabul edilmiştir. Whistleblowingin "içsel açık etme", "dışsal açık etme", "gizli açık etme" ve "destekçi açık etme" alt boyutları anlamlı düzeyde lider üye etkileşiminin "duygulanım", "sadakat", "katkı", ve "profesyonel saygı" alt boyutlarınca etkilenmektedir. $\mathrm{Bu}$ bulgular neticesinde "Duygulanım whistleblowing boyutların olumlu yönde etkilemektedir" olarak ifade edilen $\mathrm{H}_{3 \mathrm{a}}$ ve "Sadakat whistleblowing olumlu yönde etkilemektedir" olarak ifade edilen $\mathrm{H}_{3 \mathrm{~b}}$ kabul edilmiştir. Bununla birlikte; "Katkl whistleblowing boyutlarını olumlu yönde etkilemektedir" olarak ifade edilen $\mathrm{H}_{3 \mathrm{c}}$ ve "Profesyonel saygl whistleblowing boyutların olumlu yönde etkilemektedir" olarak ifade edilen $\mathrm{H}_{3 \mathrm{~d}}$ kısmen kabul edilmiştir.

İlgili alan yazın incelendiğinde örgütsel sağlık, lider üye etkileşimi ve whistleblowing kavramlarını bir arada ele alarak aralarındaki ilişkiyi belirlemeye yönelik gerçekleştirilen herhangi bir araştırmaya rastlanılmamıştır. Dolayısıyla bu durum gerçekleştirilen araştırmanın özgünlüğünü ortaya çıkartmaktadır. Sadece Altıntaş (2019), Altıntaş ve Özata (2020) ve Mansueti ve diğerleri (2016) tarafından gerçekleştirilen çalışmalarda değişkenler incelenmiştir. Altıntaş (2019) ve Altıntaş ve Özata (2020) tarafından gerçekleştirilen çalışmalarda örgütsel sağlık ve whsitleblowing kavramları ele alınmış ve iki değişken arasında pozitif yönlü anlamlı ilişkiler tespit edilmiştir. Mansueti ve arkadaşları (2016) tarafından gerçekleştirilen araştırmada ise lider üye etkileşimi ve örgütsel sağlık kavramları birlikte ele alınmış ve yine iki değişken arasında pozitif yönlü anlamlı ilişkiler tespit edilmiştir.

Sonuç olarak, örgütsel sağlık durumu artış gösterdikçe whistleblowing davranışlarının ve lider üye etkileşiminin de artış gösterdiği gözlemlenmektedir. 
$\mathrm{Bu}$ araştırma sonucunda ortaya konulan sonuçlar; çözülmesi amaçlanan problem, ele alınan değişkenler, kullanılan yöntem, belirlenen örneklem ve başvurulan istatistiksel analiz teknikleri kapsamında üretilmiştir. Dolayısıyla bir dizi sınırlılık mevcuttur. Bu sınırlılıkları da ele alarak, gelecekte yapılacak çalışmalar için araştırmacılara çeşitli öneriler getirmek mümkündür. Araştırmanın değişkenler anlamında kapsamını örgütsel sağlık, lider-üye etkileşimi ve whistleblowing oluşturmaktadır. Gerçekleştirilen bu araştırma kesitsel (cross-sectional) bir araştırma olup, nedensel ilişkilerin çok daha net bir şekilde ortaya konulabilmesi adına ilerleyen dönemlerde gerçekleştirilecek araştırmaların söz konusu ilişkileri boylamsal (longitudinal) araştırma tasarımında ele alması önerilmektedir. Gelecekte yapılacak çalışmalarda bu değişkenlere ek olarak ya da herhangi bir tanesi ile psikolojik güçlendirme, örgütsel vatandaşlık davranışı, tükenmişlik, iş performansı veya iş tatmini değişkenleri ile bir arada incelenebilir. Ek olarak modelde değişiklikler yapılarak değişkenleri modelde farklı rollerde aracı (mediator) ve düzenleyici (moderator) değişken olarak de ele alıp etkileri ölçülebilir.

Araştırmada kapsamında yer alan değişkenler, farklı ölçekler kullanılarak yeniden araştırılabilir. Böylece ölçeklerin kavramı ölçmesi konusunda ne gibi farklılıklar veya benzerlikler olduğu ortaya çıkarılabilir. Araştırmada kolayda örnekleme tekniği ile anket formu aracılığıyla veri toplanmıştır. Gelecekte yapılacak çalışmalarda olasılıklı örnekleme veya tabakalı örnekleme teknikleri kullanılması konuya dair farklı bakış açılarının geliştirilmesine yardımcı olacaktır. Bununla birlikte nitel araştırma yöntem modelleri ve yüz yüze mülakatlar aracılığıyla veri toplanması, konunun daha derinlemesine irdelenmesini sağlayabilecek, otel çalışanlarının konuya dair öznel duygu ve düşüncelerinin ortaya çıkarılmasına yardımcı olacaktır. Son olarak araştırma Doğu Akdeniz bölgesinde faaliyet gösteren iki adet beş yıldızlı otel işletmelerinin çalışanları örnekleminde yapılmıştır. Bu bağlamda ilerleyen dönemlerde araştırmacıların farklı sektörlerden ve meslek dallarından bireylerin dahil edildiği örneklemler üzerinde, çeşitli algı veya davranış değişkenleriyle ilişkili konuları bağdaştırarak söz konusu tutumların neden ve sonuçlarının tespit etmeleri ve çözüm önerileri ortaya koymaları tavsiye edilmektedir.

Bununla birlikte araştırmacı ve uygulayıcılara şu öneriler de sunulmaktadır:

- Sağlıklı bir örgüt yapısı oluşturabilmek adına sağlıklı bir iletişim ağı kurmak gerekmektedir. Örgütlerde kuralların, normların, desteğin, hedeflerin, güvenin ve bilginin paylaşılacağı doğru, akıcı, net ve kesintisiz bir iletişim ağının kurulması gerekmektedir.

- Çalışanlar, kişisel amaç ve beklentilerinin örgütsel amaç ve beklentiler ile ne kadar uyumlu olduğunu fark ettiklerinde işe yönelik davranışlarında iyileşmeler meydana geleceği için kişiörgüt uyumu teorisi kapsamında örgütsel ve bireysel amaç ve beklentiler uyumlaştırılmalıdır.

- Çalışanların sosyal birer varlık olduğu unutulmamalı, psikolojik ve duygusal gereksinimleri dikkate alınmalıdır. Psikolojik danışmanlık, ruhsal yardım, rehberlik, duygu yönetimi gibi profesyonel adımlarla bireylere psikolojik ve duygusal destekler verilmelidir.

- Örgütlerde yöneticilerin çalışanların istek, beklenti, ihtiyaç, duygu ve düşüncelerine değer veren, yüksek kalitede ilişkiler geliştirmeye özen gösteren, kariyer gelişimlerine destek olan ve onlara tatmin edici, huzurlu ve özerklik sağlanabilen bir çalışma ortamı kurması gerekmektedir.

- Yöneticiler ortaya çıkması muhtemel etik ve ahlak dışı uygulama ve davranışlardan haberdar olabilmek için içsel açık etme davranışlarını cesaretlendirmelidir.

- Bireylere iş güvencesi verilmeli ve içsel açık etme davranışları sergileyen çalışanlar ödüllendirilmelidir.

- Açık etme davranışında bulunan bireylerin olası misilleme davranışları ve yaptırımlardan korunabilmesi adına yasal zeminlerde kolay anlaşılır ve kapsayıcı sistemler oluşturulmalıdır. 
Etik Beyan: Bu çalışmada kullanılan anket yöntemi için Mersin Üniversitesi Etik Kurulu'ndan 14/01/2021 tarihli toplantısında 03/02/2021-02 sayll kararı ile izin alınmıștır. Aksi bir durumun tespiti halinde AKAD Dergisinin hiçbir sorumluluğu olmayıp, tüm sorumluluk çalışmanın yazar (lar) ina aittir.

Yazar Katkı Beyanı:1. Yazarın katkı oranı \%50, 2. Yazarın katkı oranı ise \%50'dir.

Çıkar Beyanı: Yazarlar arasında çıkar çatışması yoktur.

Ethics Statement: Permission for this study was obtained from the Ethics Committee of Mersin University at the meeting dated 14/01/2021 and numbered 03/02/2021-02 of the relevant board. In case of detection of a contrary situation, AKAD Journal has no responsibility and all responsibility belongs to the author (s) of the study.

Author Contributions Statement: 1st author's contribution rate 50\%, 2nd author's contribution rate $50 \%$.

Conflict of Interest: There is no conflict of interest among the authors.

\section{KAYNAKÇA}

Akbaba Altun, S. (2001). Örgüt să̆lı̆̆l. Nobel Yayın Dağıtım.

Aktan, C. C. (2015). Organizasyonlarda yanlış uygulamalara karşı bir sivil erdem, ahlaki tepki ve vicdani red davranış1: Whistleblowing. Organizasyon ve Yönetim Bilimleri Dergisi, 7(2), 19-36. https://dergipark.org.tr/en/pub/oybd/issue/36068/404992

Altıntaş, M. (2019). Örgütsel sağllk ve erdemli raporlama (whistleblowing) arasındaki ilişkinin araştırılması: Eğitim ve sağlık kuruluşları örneği (Yayın No. 547111) [Yüksek Lisans Tezi, Kırşehir Ahi Evran Üniversitesi] Yüksek Öğretim Kurumu Tez Merkezi. https://tez.yok.gov.tr/UlusalTezMerkezi/tezSorguSonucYeni.jsp

Altıntaş, M., \& Özata, M. (2020). Researching the relationship between organizational health and whistleblowing behavior: Education and health organizations version. Journal of International Healt Sciences and Management, 6(10), 12-34. https://dergipark.org.tr/tr/pub/jihsam

Andersen, J. A. (2006). Leadership, personality and effectiveness. The Journal of SocioEconomics, 35(6), 1078-1091. https://doi.org/10.1016/j.socec.2005.11.066

Argyris, C. (1958). The organization: What makes it healthy?. Harvard Business Review, 36(6), 107116.

Argyris, C. (1964). Integrating the individual and the organization. John Wiley \& Sons.

Ayar, M. (2020). Să̆llk sektöründe açık etme (Whistleblowing). Astana Yayınları.

Baş, T., Keskin, N., \& Mert, İ. S. (2010). Lider üye etkileşimi (LÜE) modeli ve ölçme aracının Türkçe'de geçerlik ve güvenilirlik analizi. Ege Akademik Bakış, 10(3), 1013-1039. https://dergipark.org.tr/tr/pub/eab

Blake, R. R., \& Mouton, J. S. (1985). The managerial grid (3rd ed.). Gulf Publishing Company.

Büyüköztürk, Ş. (2000). Sosyal bilimler için veri analiz el kitabı (10. bask1). Pegem Yayınları.

Cashman, J., Dansereau Jr. F., Graen, G., \& Haga, W. J. (1976). Organizational understructure and leadership: A longitudinal investigation of the managerial role-making process. Organizational Behavior and Human Performance, 15(2), 278-296. https://doi.org/10.1016/0030$\underline{\text { 5073(76)90042-8 }}$

Celep, C., \& Konakl1, T. (2012). Bilgi uçurma: Eğitim örgütlerinde etik ve kural dışı uygulamalara yönelik bir tepki. E-International Journal of Educational Research, 3(4), 65-88. http://www.eijer.com/en/pub/issue/8020/105358

Cemaloğlu, N. (2011). Primary principals' leadership styles, school organizational health and workplace bullying. Journal of Educational Administration, 49(5), 495-512. https://doi.org/10.1108/09578231111159511 
Cevrioğlu, E. (2007). Lider-üye etkileşimi ile bireysel ve örgütsel sonuçlar arasındaki ilişki: Ampirik bir inceleme (Yayın No. 205628) [Doktora tezi, Afyonkarahisar Kocatepe Üniversitesi] Yüksek Öğretim Kurumu Tez Merkezi. https://tez.yok.gov.tr/UlusalTezMerkezi/tezSorguSonucYeni.jsp

Chen, R., \& Wong, K. A. (2004). The determinants of financial health of Asian İnsurance companies. The Journal of Risk and Insurance, 71(3), 469-499. https://doi.org/10.1111/j.00224367.2004.00099.x

Dansereau Jr. F., Graen, G., \& Haga, W. J. (1975). A vertical dyad linkage approach to leadership within formal organizations: A longitudinal investigation of the role making process. Organizational Behavior and Human Performance, 13(1), 46-78. https://doi.org/10.1016/0030-5073(75)90005-7

Deluga, R. J., \& Perry, J. T. (1994). The role of subordinate performance and ingratiation in leadermember exchanges. Group \& Organization Management, 19(1), 67-86. https://doi.org/10.1177/1059601194191004

Dienesch, R. M., \& Liden, R. C. (1986). Leader-member exchange model of leadership: A critique and further development. Academy of Management Review, 11, 618-634. https://doi.org/10.5465/amr.1986.4306242

Doğan, A., \& Bozkurt, S. (2008). İstanbul ilindeki beş yıldızlı otellerin örgütsel sağlık durumlarının çalışanların algıları ile ölçümüne yönelik bir araştırma. Yönetim Dergisi: İstanbul Üniversitesi İşletme Fakültesi İşletme İktisadl Enstitüsü, $19(60), \quad$ 61-73. https://iupress.istanbul.edu.tr/en/journal/imj/article/istanbul-ilindeki-bes-yildizli-otellerinorgutsel-saglik-durumlarinin-calisanlarin-algilari-ile-olcumune-yonelik-bir-arastirma

Dulebohn, J. H., Bommer, W. H., Liden, R. C., Brouer, R. L., \& Ferris, G. R. (2012). A meta-analysis of antecedents and consequences of leader-member exchange: Integrating the past with an eye toward the future. Journal of Management, 38(6), 1715-1759. https://doi.org/10.1177/0149206311415280

Erdem, F. S. (2008). Organizasyonlarda lider-üye etkileşiminin örgütsel vatandaşlık davranışı üzerindeki etkilerinde izlenim yönetimi davranışının rolü: Kayseri'de hizmet sektöründe bir araştırma. [Yüksek lisans tezi, Erciyes Üniversitesi] Yüksek Öğretim Kurumu Tez Merkezi. https://tez.yok.gov.tr/UlusalTezMerkezi/tezSorguSonucYeni.jsp

Graen, G. B. (1976). Role making processes within complex organizations. In M. D. Dunnette (Ed.), Handbook of industrial and organizational psychology (pp. 1201-1245). Rand-McNally.

Graen, G. B., \& Cashman, J. (1975). A role-making model of leadership in formal organizations: A developmental approach, In J. G. Hunt, \& L. L. Larson (Eds.), Leadership frontiers (pp. 143166). Kent State University Press.

Graen, G. B., \& Scandura, T. A. (1987). Toward a psychology of dyadic organizing. Research in Organizational Behavior, 9, 175-208. https://psycnet.apa.org/record/1988-15584-001

Graen, G. B., \& Uhl-Bien, M. (1995). Relationship-based approach to leadership: Development of leader-member exchange (LMX) theory of leadership over 25 years: Applying a multi-level multi-domain perspective. The Leadership Quarterly, 6(2), 219-247. https://doi.org/10.1016/1048-9843(95)90036-5

Graen, G. B., Wakabayashi, M., Graen, M. R., \& Graen, M. G. (1990). International generalizability of American hypothesis about Japanese management progress: A strong inference investigation. The Leadership Quarterly, 1(1), 1-23. https://doi.org/10.1016/1048-9843(90)90012-7

Gül, H. (2007). İş stresi, örgütsel sağlık ve performans arasındaki ilişkiler: Bir alan araştırması. Karamanoğlu Mehmetbey Üniversitesi Sosyal ve Ekonomik Araştırmalar Dergisi, (2), 318-332. https://dergipark.org.tr/tr/pub/kmusekad/issue/10223/125689

Gürbüz, S., \& Şahin, F. (2014). Sosyal bilimlerde araştırma yöntemleri felsefe-yönetim-analiz. Seçkin Yayıncilik. 
Hersh, M. A. (2002). Whistleblowers-heroes or traitors?: Individual and collective responsibility for ethical behaviour. Annual reviews in Control, 26(2), 243-262. https://doi.org/10.1016/S1367$\underline{5788(02) 00025-1}$

Herzberg, F., Mausner, F., \& Snyderman, B. V. (1959). The motivation to work. John Wiley \& Sons.

Hoffman, B. J., Blair, C. A., Meriac, J. P., \& Woehr, D. J. (2007). Expanding the criterion domain? A quantitative review of the OCB literature. Journal of Applied psychology, 92(2), 555-566. https://doi.org/10.1037/0021-9010.92.2.555

Kang, D., \& Stewart, J. (2007). Leader-member exchange (LMX) theory of leadership and HRD: Development of units of theory and laws of interaction. Leadership \& Organization Development Journal, 28(6), 531-551. https://doi.org/10.1108/01437730710780976

Karasar, N. (2005). Bilimsel araştırma yöntemi kavramlar-ikeler-teknikler. Nobel Yayın Dağıtım.

Koçel, T. (2013). İşletme yöneticiliği (13. baskı). Beta Yayınevi.

Korkmaz, M. (2007). Örgütsel sağl1k üzerinde liderlik stillerinin etkisi. Kuram ve Uygulamada Eğitim Yönetimi, 49(49), 57-91. https://dergipark.org.tr/en/pub/kuey/issue/10348/126742

Kozak, M. A., \& Şahin, S. (2018). Bilgi ifşası (whistleblowing) ve etik ikilem üzerine çıkarımlar. Anatolia: Turizm Araştırmaları Dergisi, 29(1), 1-8. https://doi.org/10.17123/atad.435726

Kurum, G. (2013). Trakya Üniversitesinde görev yapan öğretim elemanlarının örgüt sağlı̆̆l algıları ile örgütsel güven düzeyleri arasındaki ilişki (Yayın No. 358339) [Yüksek lisans tezi, Trakya Üniversitesi] Yüksek Öğretim $\quad$ Kurumu $\quad$ Tez $\quad$ Merkezi. https://tez.yok.gov.tr/UlusalTezMerkezi/tezSorguSonucYeni.jsp

LePine, J. A., Erez, A., \& Johnson, D. E. (2002). The nature and dimensionality of organizational citizenship behaviour: A critical review and metaanalysis. Journal of Applied Psychology, 87(1), 52-65. https://doi.org/10.1037//0021-9010.87.1.52

Liden, R. C., \& Maslyn, J. M. (1998). Multidimensionality of leader-member exchange: An emprical assessment through scale development. Journal of Management, 24(1), 43-72. https://doi.org/10.1016/S0149-2063(99)80053-1

Lyden, J. A., \& Klingele, W. E. (2000). Supervising organizational health. Supervision, 61(12), 3-6. https://www.proquest.com/docview/195591888?accountid=86205

Mansueti, N., Grazia Grandi, M., \& Grazio, A. (2016). The leader member exchange (LMX) in organizational health context. Observational study at the department of rehabilitation. International Journal of Medicine and Pharmacy, 4(1), 1-38. https://doi.org/10.15640/ijmp.v4n1a1

Maslow, A. H. (1965). Eupsychian management. Irwin-Dorsey Press.

McGregor, D. M. (1960). The human side of the enterprise. McGraw-Hill.

Miles, M. B. (1969). Planned change and organizational health: Figure and ground. In F. D. Carver, \& T. J. Sergiovanni (Eds.), Organizations and human behavior (pp. 375-391). McGraw-Hill.

Near, J. P., \& Miceli, M. P. (1985). Organizational dissidence: The case of whistle-blowing. Journal of Business Ethics, 4(1), 1-16. https://doi.org/10.1007/BF00382668

Porter, L. W., \& Lawler, E. E. (1968). Managerial attitudes and performance. Irwin-Dorsey Press.

Sandıkçı, M., Vural, T., \& Zorlu, Ö. (2015). Otel işletmelerinde dönüştürücü liderlik davranışlarının örgüt sağllğı üzerine etkileri: Afyonkarahisar ilinde bir araştırma. Yönetim Bilimleri Dergisi, 13(25), 161-200. https://dergipark.org.tr/en/pub/comuybd/issue/43594/533802

Settoon, R. P., Bennett, N., \& Liden, R. C. (1996). Social exchange in organizations: Perceived organizational support, leader-member exchange, and employee reciprocity. Journal of Applied Psychology, 81(3), 219-227. https://doi.org/10.1037/0021-9010.81.3.219 
Shoaf, C., Genaidy, A., Karwowski, W., \& Huang, S. H. (2004). Improving performance and quality of working life: A model for organizational health assessment in emerging enterprises. Human Factors and Ergonomics in Manufacturing \& Service Industries, 14(1), 81-95. https://doi.org/10.1002/hfm.10053

Taylor, E. Z., \& Curtis, M. B. (2010). An examination of the layers of workplace influences in ethical judgments: Whistleblowing likelihood and perseverance in public accounting. Journal of Business Ethics, 93(1), 21-37. https://doi.org/10.1007/s10551-009-0179-9

Tsui, K. T., \& Cheng, Y. C. (1999). School organizational health and teacher commitment: A contingency study with multi-level analysis. Educational Research and Evaluation, 5(3), 249268. https://doi.org/10.1076/edre.5.3.249.3883

Tutar, H. (2016). Örgütsel davranış (örgüt teorileri ve çağdaş yaklaşımlar açısından). Detay Yayıncilik.

Ural, A., \& Kılıç, İ. (2013). Bilimsel araştırma süreci ve SPSS ile veri analizi. Detay Yayınc1lık.

Usenyag, S., Trichandhara, K., \& Rinthaisong, I. (2017). Antecedents of organizational health in southern Thailand. The Journal of Behavioral Science, 12(1), 79-94. https://so06.tcithaijo.org/index.php/IJBS/article/view/75884

Ünlü, M. (2011). Örgüt să̆lı̆̆ algısının çalışma yaşamı kalitesi üzerine etkisi: İzmir Gaziemir ilçesindeki ortaögretim kurumları uygulaması (Yayın No. 333271) [Yüksek lisans tezi, Dokuz Eylül Üniversitesi] Yüksek Öğretim Kurumu Tez Merkezi. https://tez.yok.gov.tr/UlusalTezMerkezi/tezSorguSonucYeni.jsp

Vroom, V. H. (1964). Work and motivation. John Wiley \& Sons.

Wayne, S. J., Liden, R. C., \& Sparrowe, R. T. (1994). Developing leader-member exchanges: The influence of gender and ingratiation. American Behavioral Scientist,37(5), 697-714. https://doi.org/10.1177/0002764294037005009

Yukl, G. (1989). Leadership in organizations. (2nd ed.). Prentice-Hall.

Zalesny, M. D., \& Graen, G. B. (1987). Exchange theory in leadership research. In A. Kieser, G. Reber, \& R. Wanderer (Eds.), Handbook of leadership (pp. 714-727). C.E. Paeschel, Verlag.

Zel, U. (2006). Kişilik ve liderlik. Nobel Yayınları. 